\title{
MAKING ROOM FOR WHOM? CO-LIVING AS A REINVENTION OF ROOMING HOUSES FOR THE COMMODIFIED CITY
}

\author{
by \\ Jonathan Mak \\ BA, University of British Columbia, 2017 \\ A Major Research Paper \\ presented to Ryerson University \\ in partial fulfillment of the requirements for the degree of \\ Masters of Planning \\ in \\ Urban Development
}

Toronto, Ontario, Canada, 2020

(C) Jonathan Mak 2020 


\section{Author's Declaration for Electronic Submission of an MRP}

I hereby declare that I am the sole author of this MRP. This is a true copy of the MRP, including any required final revisions.

I authorize Ryerson University to lend this paper to other institutions or individuals for the purpose of scholarly research.

I further authorize Ryerson University to reproduce this MRP by photocopying or by other means, in total or in part, at the request of other institutions or individuals for the purpose of scholarly research.

I understand that my MRP may be made electronically available to the public. 


\title{
MAKING ROOM FOR WHOM? CO-LIVING AS A REINVENTION OF ROOMING HOUSES FOR THE COMMODIFIED CITY
}

\author{
(C) Jonathan Mak, 2020 \\ Masters of Planning \\ in \\ Urban Development \\ Ryerson University
}

\begin{abstract}
Co-living, a form of living characterized by individually rented rooms with shared amenities, is framed by proponents as an innovative form of housing that addresses many ills of contemporary urban life, such as housing affordability and isolation. However, the practice of renting individual rooms is not new, providing some of the lowest-cost market housing in North American cities including Toronto. I trace the lineage of various forms of collective living to conceptualize the roots of co-living. I argue that the rise of contemporary co-living and the decline of rooming houses in urban centres are part of the same process of urban transformation associated with gentrification. Through interviews and chats with planners in Ontario and representatives from co-living companies, I compare the perspectives of various coliving stakeholders. I then explore the possible effects of the proliferation of co-living on housing affordability and rooming houses and what it means for policymakers moving forward.
\end{abstract}

Key words: co-living, rooming houses, housing, gentrification 


\section{Table of Contents}

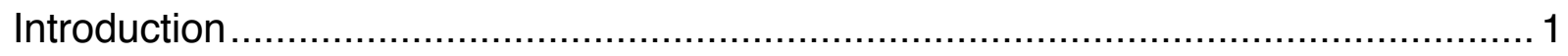

Changing attitudes, norms, and regulations of living arrangements.......................... 6

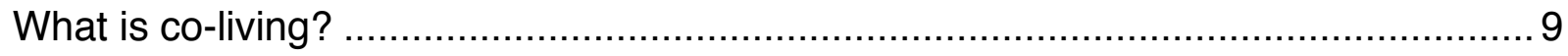

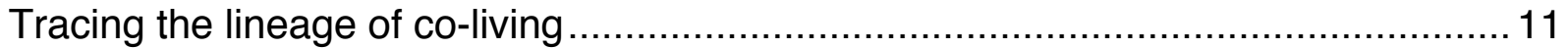

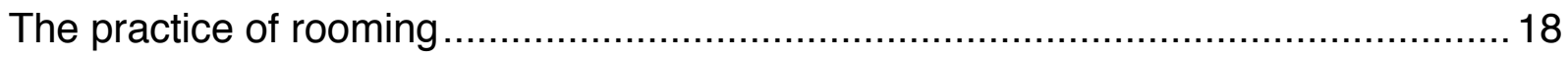

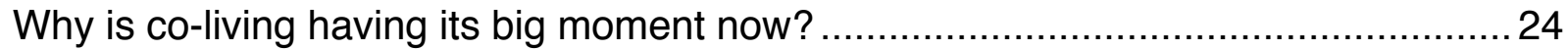

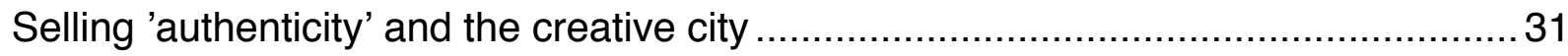

Moving forward: co-living in Toronto and wider implications .................................. 34

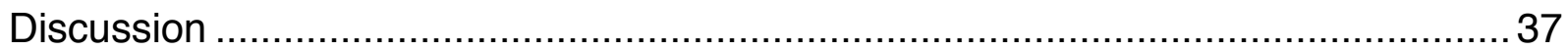

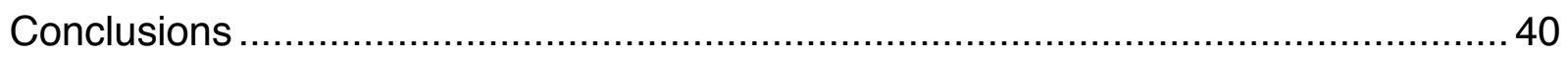

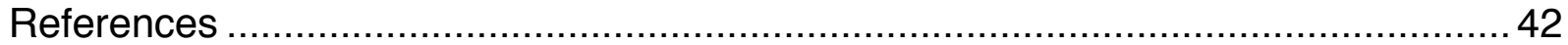




\section{Introduction}

In the mid- to late-2010s, 'co-living' emerged in major cities as a 'new' and 'innovative' form of housing. Co-living is typically characterized by rooms that are individually rented out, with amenities shared among tenants, such as kitchens, bathrooms, and living rooms. However, co-living is marketed as much more than a form of accommodation-it is often framed as an innovative form of living that fosters community and addresses many contemporary ills of urban living, such as high housing costs and isolation. Co-living projects have emerged as a worldwide phenomenon in many high-cost cities, including San Francisco, New York, London, Bangalore, Beijing, São Paulo, Cape Town, Sydney, and Toronto. The Collective, a large co-living apartment complex in London, UK, that houses 550 residents describes co-living as an "innovative way of living that combines thoughtfully designed private space with one-ofa-kind amenities and ground-breaking experiences" (The Collective, 2020). WeLive, the co-living division of WeWork, positions itself as a "new way of living is inhabiting time, space, and place that stirs inspiration inside of us," and a model that will "transform the rigid and isolating housing model of yesterday into a flexible and community-driven experience for today" (WeLive, 2020).

The practice of living in shared spaces with unrelated people has existed in all of recorded history on all continents. However, with industrialization, urbanization, and associated changes in social structures, single-family homes and the institution of the nuclear family became the norm in Canada, the United States, and Western Europe. Even so, the practice of lodging in another family's home was widespread in large cities 
across North America in the 19th and early 20th centuries (Harris, 1992). The practice was especially common in Toronto; the 1931 census reported that almost a quarter of households contained one or more lodgers. However, by the mid-1900s, the practice of rooming had become a stigmatized and marginal form of housing, with cultural commentators and policymakers arguing against rooming broadly, claiming that the practice encouraged immorality, threatened the traditional values of family life, caused overcrowding and disease, and invaded privacy (Modell \& Hareven, 1973; Harris, 1992).

The dominance of these social attitudes has widely influenced regulations on living arrangements. Restrictions have been placed on apartments on the same normative moralistic grounds. Social commentators argued that apartments could never be homes, and provided unsuitable environments to raise children, and encouraged immorality among women by reducing the amount of housework they needed to do and providing them access to public spaces (Dennis, 2000). Apartments were painted with the same brush as tenements and were branded as unsanitary, unsafe, ill-ventilated, and overcrowded (Harris, 1992; Dennis, 2000). The antipathy toward apartment construction often resulted in reduced property values for adjacent single-family dwellings, and as a result, homeowners and real-estate interests worked to restrict apartment construction (Dennis, 1994; Weaver, 1987).

These social attitudes permeate land-use policy and continue to influence policy that limits acceptable land uses. Despite still facing restrictive land-use policies in large parts of Toronto, apartments have become widely normalized as a form of housing. 
However, rooming houses have not faced a similar process of destigmatization, and are associated with poverty, poor health, and crime, becoming a maligned and stigmatized form of housing (Grant et. al., 2019). As one of the cheapest forms of housing in the private market, rooming houses form an indispensable part of the housing stock in Toronto, which had a social housing waitlist of over 102,000 in 2019 (City of Toronto, 2019).

Traditionally, rooming houses have been located in downtown cores that experienced urban decline with suburbanization. However, the process of gentrification has brought significant neighbourhood change to the downtown areas where rooming houses have typically been located. In Toronto, the number of downtown rooming houses have been declining since the 1970s, while rooming houses have proliferated in the inner suburbs in areas they are illegal and unregulated (Campsie, 2018). This follows the spatial patterns of income polarization in Toronto noted by Hulchanski (2010), with a disappearing middle-income city with high-income areas increasingly concentrating downtown with poverty concentrating in the inner suburbs.

Concurrently, co-living has grown in rapidly gentrifying urban centres all over the world. This trend can be seen in cities worldwide in San Francisco, London, Bangalore, Beijing, São Paulo, Cape Town, Sydney, and Toronto, and many other cities globally. In San Francisco's historically working-class and Hispanic Mission District, Starcity offers rooms in a 20 -unit renovated Victorian home starting at $\$ 1,799$ USD per month $(\$ 2,400$ CAD) (Starcity, 2020). The Collective offers rooms in a 705-unit purpose-built development in Canary Wharf starting at $£ 1430$ per month $(\$ 2,450$ CAD) (The 
Collective, 2020). Stey offers rooms in a 44-unit refurbished building in central Beijing for 12,000 CNY per month ( $\$ 2,320$ CAD) (Stey, 2020). Co-living companies are typically able to provide cost-savings over market rents for studio and one-bedroom apartments in cities with high housing costs.

What exactly is co-living though? The desire for alternative living arrangements with an emphasis on community is not new. An antecedent to co-living can be found in the co-housing movement, which emerged in Denmark as a community-oriented model with both utopian and pragmatic roots (Tummers, 2015). At its core, it is a form of collaborative housing that is self-managed, typically with smaller private dwellings to maximize space for common facilities (Tummers, 2015; Jarvis, 2011). Similarly, coliving is framed by proponents as more than an economic response to high costs of housing, but rather a 'disruptive' and 'innovative' form of housing that will address many of the ills of modern city living, including affordability as well as building a sense of 'community' to address urban loneliness. This idea of intentionality in community, as well as a larger bundle of amenities, sets co-living sets it apart from traditional rooming houses, although as a living arrangement, they share similarities and are classified as such in Toronto. The additional amenities and rhetoric of community serve to overcome the stigma associated with rooming houses and make it palatable to a wealthier demographic.

By tracing the lineage of co-living, identifying its ideological roots, and analyzing the cultural and economic conditions that led to the rise of co-living globally, I argue that co-living is a commodified form of collective living arising out of urban conditions related 
to gentrification. Co-living takes both the pragmatic and utopian narratives associated with co-housing and packages it with the tech-startup rhetoric of 'innovation' to sell a product to a demographic of young urban professionals that have been settling in downtown areas globally. These aesthetic tastes and sensibilities of this demographic are uniform across cities worldwide and put a focus on authenticity in cultural experiences. The commodification of 'authentic urban experiences' builds on the role of artists and aestheticization in the field of gentrification presented by Ley (2003), as well as Zukin's (2009) observations of the role of 'authenticity' and the search thereof as a powerful lever to claim urban space. The marketing of a uniform global urban sense of 'authenticity' may seem to present inherent contradictions but have proved to be a successful tool in the transformation of urban space, lauded by those who have embraced Richard Florida's creative city narratives of economic development. The products that co-living companies offer repackage rooming houses, a stigmatized and maligned form of housing, into an 'authentic' and 'community-oriented' experience for higher-income young professionals in the 'creative city'.

The above conclusions are drawn from a review of the literature and primary data collection. I first explore the contemporary context of co-living and trace its roots back to older forms of communal living. Next, I connect the disparate effects of gentrification on low-income rooming houses in urban centres and the rise of contemporary co-living, a form of rooming that has been repackaged for higher income groups. Finally, I discuss the future of co-living in Toronto, with information gathered from interviews I conducted in-person, over the phone, and over email with city planners in Toronto and Kitchener, 
as well as with representatives of co-living companies operating in Toronto. These findings outline the implications of the growth of co-living on rooming house policy in Toronto. From this, I argue that the growth of the practice of rooming for higher income groups may destigmatize the practice but may also complicate municipal policies in regard to rooming houses.

\section{Changing attitudes, norms, and regulations of living arrangements}

Social attitudes can have a large effect on the kinds of living arrangements and built forms that are allowed within a city. The history of the state's regulation of the household and the family is extensive and often overlooked when considering the forms, typologies, and household structures of private homes. The dominant narrative of the nuclear family single-family home as the ideal has permeated the policies and regulations around the forms and arrangements of housing that is permitted and continue to influence policy, zoning, regulations on the allowable relations in cohabitation. Regulations also extended into private living arrangements and the allowable relations of dwelling-unit inhabitants. For example, zoning regulations in North York, Ontario, in the 1970s limited the use of certain residential zones to dwellings, semi-detached dwellings, and duplex dwellings, with dwellings defined as a separate set of living quarters designed or intended for use by an individual or one family alone. The definition of "family" was limited to a "group of two or more persons living together and interrelated by bonds of consanguinity, marriage or legal adoption occupying a dwelling unit" (Bell v. R., 1979). 
While apartments are now widespread, many of the arguments and criticism levelled against multi-family housing were similar to arguments against rooming houses, with arguments that they could never be 'homes', provided unsuitable environments in which to raise children, and encouraged immorality among women by reducing the amount of housework they needed to do and providing them access to public spaces (Dennis, 2000). Apartments were painted with the same brush as tenements and were branded as unsanitary, unsafe, ill-ventilated, and overcrowded (Harris, 1992; Dennis, 2000). The antipathy toward apartment construction often resulted in reduced property values for adjacent single-family dwellings, and as a result, homeowners and real-estate interests worked to restrict apartment construction (Dennis, 1994). In Toronto, a group of property owners was able to lobby City Council to pass a bylaw which prohibited the construction of apartment buildings in the city, aside from specific parcels that were exempt (Harris, 1992). In the early 1900s, restrictive covenants were occasionally used to exclude all but single-family dwellings. Following this, bylaws were passed to restrict the construction of apartments on streets with single-family homes, which were precursors of more comprehensive zoning schemes (Harris, 1992). In many ways, the question of how much density is too much density still drives NIMBY concerns and restricts structural density as well as the density of residents in small spaces.

Cities have placed restrictions and regulations on rooming houses with numerous rationales. The City of Waterloo's rental housing bylaw raised was deemed 'discriminatory' by the Ontario Human Rights Commission (OHRC) due to a licensing and regulatory regime that "might discriminate against groups protected under the 
Ontario Human Rights Code" (OHCR, 2013, p. 1). The bylaw established per-person floor area requirements for bedrooms, minimum separation distances between rooming houses, gross floor area requirements, and licensing fees, all of which the OHCR found discriminatory (OHCR, 2013). The City of Kitchener's zoning bylaw retains minimum separation distances between rooming houses but are subject to change in the new zoning bylaw as a part of their Affordable Housing Strategy work (G. Stevenson, personal communication, Feb 5, 2020).

In some other cities there are co-living projects in excess of 800 units - so on what grounds should a municipality limit or restrict this if people choose to live in such a fashion? Likewise, the restrictions and illegality of rooming houses in parts of Toronto drive low-income people into informal housing. The policies and regulations on rooming houses in Toronto have been a proxy for attempts to house low-income people under reasonable standards in private-market housing. With the rise of co-living, the policies and discourse surrounding rooming houses will become further complicated if regulatory regimes consider co-living rooming houses under the same umbrella as low-income rooming houses. 


\section{What is co-living?}

\begin{tabular}{|c|c|c|c|}
\hline management-style & \multicolumn{3}{|c|}{ ownership-style co-living } \\
\hline $\begin{array}{l}\text { Private condos and } \\
\text { homes managed by } \\
\text { co-living company } \\
\text { e.g. SoulRooms, } \\
\text { Toronto }\end{array}$ & $\begin{array}{l}\text { Converted homes and } \\
\text { units owned by } \\
\text { co-living company } \\
\text { e.g. Starcity Mission, } \\
\text { San Francisco }\end{array}$ & $\begin{array}{l}\text { Purpose-built small } \\
\text { co-living projects } \\
\text { e.g. Node, Kitchener }\end{array}$ & $\begin{array}{l}\text { Purpose-built small } \\
\text { co-living megaprojects } \\
\text { e.g. The Collective } \\
\text { Canary Wharf, } \\
\text { London, UK }\end{array}$ \\
\hline
\end{tabular}

Figure 1: The Spectrum of Co-living

Co-living emerged in the mid-2010s and shares many similarities with older forms of housing and living arrangements. Neither the built-form arrangement nor management structure is the defining characteristic of co-living; there are a variety of ownership, management, and built form arrangements that have all been marketed as co-living. Broadly, co-living, short for collaborative living, is characterized by individually rented units that are typically smaller-than-average, supplemented by a bundle of amenities and shared spaces, such as weekly cleanings, fully-stocked kitchens, access to recreation and amenity spaces, and social activities.

Broadly, there are two forms of management structures that co-living can takemanagement-style co-living and ownership-style co-living. In management-style coliving, co-living companies manage privately-owned homes, renting out individual rooms and providing the amenities associated with co-living, such as weekly cleanings. Under this arrangement, the unit is rented at a premium to cover the cost of management, and in return, owners of units do not have to act in the role of landlord. Co-living companies 
in Canada currently only operate under the management model, with a variety of companies operating in Toronto and Vancouver. This form of co-living typically has fewer amenities, as they operate in existing built form arrangements that are not optimized for co-living, such as condominiums and townhomes. Within Toronto, an example of a management-style co-living company is SoulRooms, a company that houses about 100 tenants in privately-owned homes spread across Toronto (A. Dastidar, personal communication, Jan 9, 2020).

Outside Canada, many co-living companies operate in an ownership-model of co-living. In this model, co-living companies do not manage private homes, but rather own the buildings or lease larger buildings on a commercial basis, similar to a hotel or co-working space. This form of co-living requires higher levels of capital investment, but also provides greater returns on investment. These co-living projects range in size, from small converted buildings being subdivided into small rooms to purpose-built megaprojects with upwards of 15,000 beds, such as the 15,000-bed co-living project in development by Olive in Bangalore, India (Pownall, 2020). Large purpose-built co-living projects have popped up in cities across the world. One of the largest co-living projects in development is Starcity Bassett, located in San Jose, California, slated to open in 2021 with 803 co-living units.

Co-living is not simply a revival of the practice of rooming for higher-income groups. What defines co-living is not necessarily the living arrangement, but the amenities and narrative of community attached to it. Municipal planners in Toronto are aware of rooming houses in the city that are rented to higher income groups than 
traditional rooming houses (C. Perez-Book, personal communication, Feb 21, 2020). These rooming houses are not co-living and do not market themselves as such, even though a level of collaboration is inherent in living in shared quarters. The intentionality of living in shared quarters counters the stigma of rooming, which has typically been associated with economic necessity.

\section{Tracing the lineage of co-living}

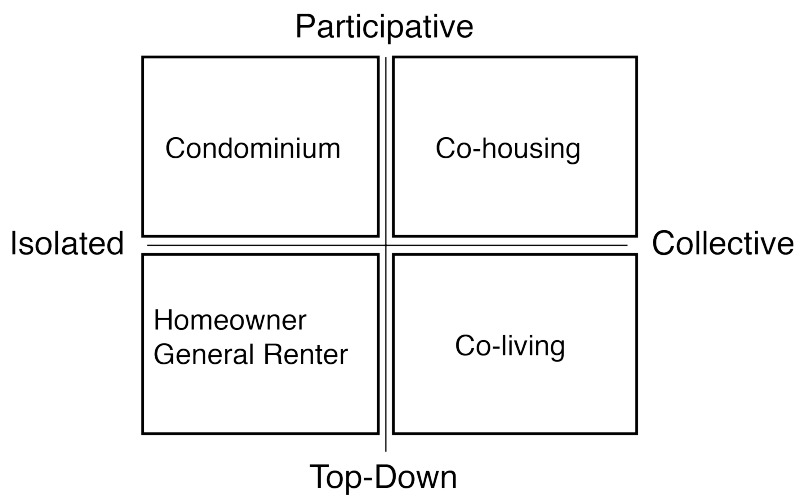

Figure 2: The realm of co-living, based on Tummers (2016)

Various scholars have attempted to characterize different forms of shared living, comparing them and defining the similarities and differences between them. Tummers (2015) characterized various forms of housing under two axes - with one axis ranging from isolated to collective, and the other ranging from participative management to topdown management. Co-housing, broadly, is a form of housing with various levels of collectivity, such as collective action, community living, mutualizing resources, and interdependency (Tummers, 2015). Co-housing is also characterized as having a participative form of management - meaning it is collectively managed in some way or another (Tummers, 2015). Co-living shares aspects of collectivity with co-housing, but is 
managed from the top-down rather than with a participatory model. The physical living arrangement, on the other hand, resembles rooming houses. Co-living is never simply framed as a cost-saving living arrangement-co-living is always associated with a package of amenities, such as weekly cleanings, stocked kitchens, and recreational common spaces, and is always accompanied with a concept of community.

The practice of living in shared spaces with unrelated people has existed in all of human history on all continents in various forms. However, the lineage of the contemporary forms of shared living movements is rooted in distinctly modern historical, political, economic, and social conditions. Although co-living is presented as an innovative solution that will help solve modern housing affordability woes, the practice of living in small quarters with shared amenities is neither new nor innovative. Rooming houses have existed in urban centres continuously since at least the 19th century. Tracing the origins of the modern 'co-living' movement and understanding the narratives of urban ills and solutions that co-living proponents follow can uncover and understanding of 'what' co-living is.

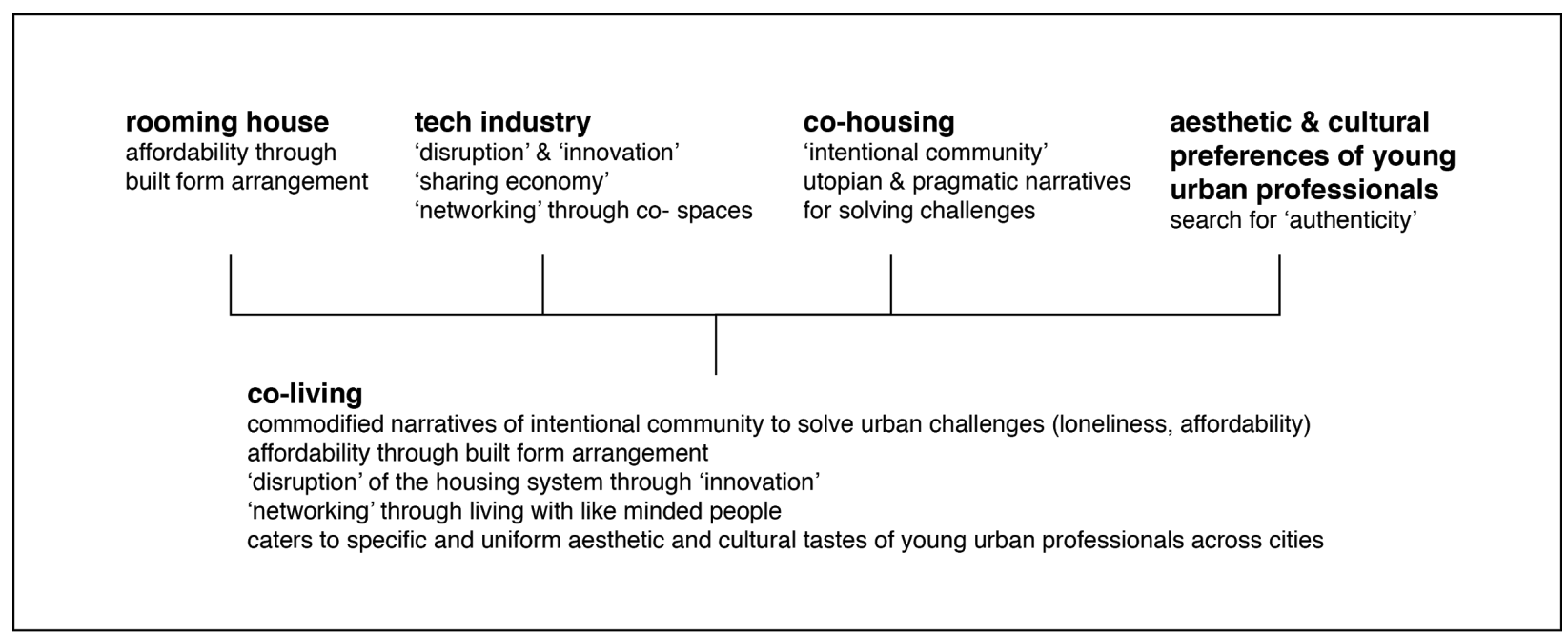

Figure 3: The ideological and pragmatic origins of co-living 
Co-living is not a distinct built form, nor is it a distinct form of tenure. In effect, the only defining feature between a traditional rooming house and a co-living development lies in its self-designation-in other words, something becomes co-living because it claims to be so. The stigma attached to 'rooming houses' is strong, and a concerted effort to rebrand this form of housing has been undertaken by co-living companies for marketing purposes. For example, Starcity markets its co-living projects as communities, and rooms are referred to as suites (Starcity, n.d.). Many co-living companies have also positioned itself as reinventing the experience of renting, distancing themselves from language typically used to describe the rental experience, such as landlord or tenant. Los Angeles-based co-living company Haven refers to residents as members rather than tenants, evoking feelings of co-ownership and horizontal management structures typical of co-operatives and co-housing communities (Haven, 2020). Uko, a co-living company based in Sydney, Australia, goes as far as to market themselves as offering studio apartments with no landlords (Uko, n.d.).

Co-living takes the economic but historically stigmatized practice of rooming, imbuing it with rhetoric of community, collaboration, and membership that typifies the co-housing movement that emerged in the 1960s. Co-housing, much like co-living, is a category of housing with fuzzy boundaries. Broadly, co-housing falls under a wide grouping of 'collaborative housing' that are self-managed (Tummers, 2016). Within the literature, co-housing often includes a wide variety of forms of housing, including housing co-operatives, intentional communities, squats, and eco-villages. What holds 
these forms of housing together is a level of intentionality in community and selfmanagement. This aspect of self-management is an important differentiating factor between co-living and co-housing. Much like co-living, living quarters are typically smaller-than-average to maximize space for common facilities and amenities to facilitate social interaction and communitas - the sense of community (Jarvis, 2011).

Co-housing can take multiple forms of tenure, including owner-occupancy, cooperative, and rental. The focus on social interaction and involvement of inhabitants are characteristics that differentiate co-housing from traditional condominiums and coownership (Tummers, 2015). Additionally, co-housing has been argued to be different from an 'ordinary' condominium because "cohousing residents usually take part in each aspect of the community's development," including the physical design process (Ruiu, 2016, p. 403). Usually, ownership and rental contracts specify an amount of work expected from adult residents per month, such as babysitting, gardening, and maintenance work (Sargisson, 2010). Common meals shared between residents are also common-all aimed at creating a sense of community (Blank, 2001; McCamant \& Durrett, 2011).

Although the co-housing movement originated in the 1970 s as a communityoriented model, the contemporary realization of co-housing is diverse. The growth of cohousing in Europe follows the trend of decentralization and an increasing focus on selfreliance to find custom-made solutions (Tummers, 2016). The growth of co-housing projects in Germany has been linked, at least in part, to the state's withdrawal from private housing funding policy. The development of co-housing communities has 
emerged as both pragmatic and idealistic responses to the challenges of living in contemporary societies (Tummers, 2015). Co-housing projects have been characterized as an example of an urban commons-an alternative, non-commodified means to fulfill social needs (Pusey \& Chatterton, 2016). However, the modern re-emergence of cohousing is typically pragmatic responses to challenges of modern life, focusing on creating more efficient organizations of family life (Kläser, 2006, in Tummers, 2016). Many influential people in the modern co-housing movement, particularly in North America, have explicitly taken an anti-utopian stance, distancing itself from the utopian and ideologically driven intentional communities and communes that formed the origin of co-housing (Sargisson, 2012). Sargisson (2012) delineates the co-housing movement into two waves, the first being an explicitly utopian movement originating in Denmark, with a second wave originating in North America abandoning utopian rhetoric and opting to position itself as a pragmatic response to challenges faced by modern households. Although McCamant \& Durrett (2011) emphasize the anti-utopian character of North American co-housing, Sargisson (2012) argues that it is still a form of intentional community and does display some utopian tendencies.

Co-housing has been linked to high levels of life satisfaction, with 87 percent of co-housing residents in Denmark reporting positive satisfaction with their living situation in a survey conducted from 2016 to 2017 (Jakobsen \& Larsen, 2018). Intentional communities (ICs) have been found to promote wellbeing and life satisfaction, regarding their lives as more purposeful than non-IC residents (Grinde et. al., 2017). Despite its small numbers, co-housing has also been seen as a potential model for sustainable and 
inclusive development (Krokfors, 2012). Policymakers across Europe, including those in Hamburg and Gothenburg, are also increasingly embracing co-housing as a means to sustainable urban development (Scheller \& Thörn, 2018). In Denmark, co-housing has evolved from being a form of alternative housing into mainstream housing in the past five decades, and discussions of "mainstreaming" have emerged in Germany in recent years (Droste, 2015; Jakobsen \& Larsen, 2019).

Despite its rhetoric of inclusive and sustainable urban development, the residents of co-housing communities are typically homogenous. There have been critiques of the co-housing trend as catering to a privileged, typically middle-class population (Tummers, 2015; 2016). Parallels between co-housing and gated communities have been drawn by some (Chiodelli, 2015; Chiodelli \& Baglione, 2014). Sanguinetti \& Hibbert (2018) found that among US cohousing residents, 95 percent were white, compared to 73 percent for the US as a whole. Additionally, 94 percent of cohousing residents were college-educated, with 66 percent of residents holding a graduate degree (Sanguinetti \& Hibbert, 2018). This is compared to 29 percent of the general US population holding a college degree, with 11 percent holding a graduate degree (Sanguinetti \& Hibbert, 2018). Likewise, co-housing residents in Denmark-often seen as the "gold standard" of co-housing, show the same trends of homogeneity and high educational levels (Jakobsen \& Larsen, 2018). Jakobsen \& Larsen (2018) found that 96.9 percent of surveyed co-housing residents were of Danish descent, compared to 87 percent for Denmark as a whole. 44.1 percent of cohousing residents had received a 
master's or Ph.D. degree, compared to 8.3 percent for Denmark as a whole (Jakobsen \& Larsen, 2018).

While there are no studies of the demographic makeup of co-housing communities in Canada, the studies conducted in Denmark and the United States show that there have been limits in the kinds of people who choose to live in co-housing communities. In many ways, the modern incarnation of co-housing is a niche product that serves a niche demographic-much like co-living. This will be discussed further in length, but in many ways, co-living takes many of the same challenges faced by similarly educated demographics, and applies it to a different context-to younger, prourban, experience- and authenticity-focused young professionals. This can be seen in the rhetoric, aesthetic and cultural preferences, and location choices that co-living companies market their product. Co-living emerged from the same technology startup environment as co-working, and many co-living companies also operate co-working spaces (and vice versa), such as WeWork and WeLive, the Collective, and Stey. The intended demographic of co-working spaces and co-living spaces overlap and fit into the larger picture of the tech industry's 'disruption' and 'reinvention' of old concepts. Media coverage of co-living has been critical at times, with Arwa Mahdawi writing in the Guardian in 2017 that "[t]he modus operandi for many tech entrepreneurs lacking ideas appears to be: just find an existing service, privatize it, and claim to have 'reinvented it'." This reinvention of rooming has been effective in destigmatizing the practice of rooming - even making it a form of housing of choice for people who could otherwise afford other living arrangements. 


\section{The practice of rooming}

While co-living is framed as an innovative form of housing, the practice of renting individual rooms with amenities shared between tenants is not a new one. The practice of lodging -the practice of people and families accommodating themselves in someone else's home-was common in cities and large towns in North America in the 19th and early 20th centuries (Harris, 1992). Lodging was not simply a matter of economic necessity; middle-class white-collar workers who could have otherwise chosen other accommodation also lodged, and many middle-class households that could have afforded not to take in a lodger did (Harris, 1992). There was a major class of lodging houses that catered to a "quite prosperous clientele, typically single businessmen" (Harris, 1992, p. 340). Lodging was not simply a matter of pure necessity; as such, historians have attempted to piece together what the practice of lodging meant in a social context (Harris, 1992; Modell \& Hareven, 1973).

There were two main forms of lodging-boarding and rooming. In principle, boarding differed from rooming by providing services in addition to a room, such as meals. At the time, rooming houses were seen as respectable accommodations for single persons and families in rapidly industrializing cities (Wolfe, 1906; Freeman, 2013). The nineteenth-century family American family was an "accommodating and flexible institution, as had been its eighteenth- and seventeenth-century predecessors" (Modell \& Hareven, 1973). As a result, the practice of lodging in someone else's home was not stigmatized and widespread. Its ubiquity is demonstrated by Walt Whitman's 
perhaps hyperbolic claim that in the mid-19th century, three-quarters of adult inhabitants in New York City lived in boarding-houses (Gamber, 2005).

The practice of lodging was especially widespread in Canada, with the incidence of lodging being more widespread in Toronto than in other cities in North America in the early 20th century. The 1931 census reported that 23.2 percent of Toronto's households contained one or more lodgers, compared to 19 percent for Canada as a whole and 11.4 percent for the United States in 1930 (Harris, 1992). The practice of lodging was not limited to the urban poor; the late 1800 s and early 1900 s were marked by significant social upheaval with rapid industrialization and urbanization, which was accompanied by significant social changes in the social arrangement of households. The entrance of young women into the workforce in the early 1900s "coincided with, and was encouraged by, the loosening of many of the social, economic, and political restraints imposed on the nineteenth-century woman (Fine, 1986, p. 511). Within this era of social change, boarding houses also served a growing young, single, white-collar population of women transitioning between home life and independent life as self-described ‘business women' (Fine, 1986). The Eleanor Association residential clubs housed thousands of single young women in Chicago between 1898 and 1930, providing "safe, respectable, home-like, low-cost housing, and a vast array of social services that allowed white-collar women to lead relatively independent lives" (Fine, 1986, p. 1). Boarding houses provided a social good in a milieu of changing social and cultural norms. 
Cultural commentators of the time argued against the practice of lodging broadly, arguing that it encouraged immorality, threatened the traditional values of family life, caused overcrowding and disease, and invaded privacy (Harris, 1992). Lawrence Veiller, an American progressive moralist reformer in the early 20th century argued that 'room overcrowding' was entirely wrapped up with the 'lodger evil' (Harris, 1992). Additionally, housing reformers associated the 'lodger evil' with immigrants, with one American housing reformer asserting that the "main reasons for the lodger evil are to be found in the gregarious habits of foreign elements" (Aronovici, 1917, pp. 51-52). In Toronto, British immigrants were likely to board in private homes, while Jewish, Macedonian, and Italian immigrants were most likely to use lodging homes in areas of 'foreign' settlement, such as the Ward (Harris, 1992). The Ward was characterized as a slum, and local reformers expressed concerns about disease and immorality. These concerns eventually led to a gradual municipally-led clearance of the Ward, with the city's original Chinatown being expropriated to make way for Nathan Phillips Square in 1950. The practice of boarding declined in the early 20th century, with hosts increasingly unwilling to provide services to lodgers. Rooming houses continued to exist but were increasingly associated with poverty, poor health, and crime, and has become a maligned and stigmatized form of housing (Grant et. al., 2019).

The basis of arguments against the practice of rooming was often levelled on the grounds of social space rather than physical space, with the implication that biologically related individuals required less space than unrelated individuals (Harris, 1992). In other words, the overcrowding, disease, invasions of privacy, and threats to traditional values 
were the result of unrelated people living in close quarters. The conventional narrative explaining the decline and stigmatization of lodging in Toronto involved the increase of cheap apartments from the 1920s onwards leading to the concentration of social marginal populations - the poor and transient-in rooming houses. (Harris, 1992). Increasingly, rooming houses and single room occupancy (SRO) hotels all across North America were occupied by the working poor, the unemployed, and 'down and outs' (Rollinson, 1991).

The history of rooming houses in Toronto has been characterized as a microcosm of the history of efforts and failures to house low-income single people (Campsie, 1994). Once seen as respectable places for students, single workers, immigrants, and newlyweds to live after leaving home or moving to the city, rooming houses underwent a process of decline and stigmatization from the 1940s onward (Campsie, 1994; Harris, 1992). Single-room occupancy (SRO) became the form of housing associated with poverty, crime, and vagrancy in skid row, from New York, San Francisco, and Vancouver (Groth, 1989). By the mid-1970s, the landscape of rooming houses in Toronto was dismal, with evictions, poor living conditions, and fatal fires being common (City of Toronto, 1974; 1977; Campsie, 1994). The City of Toronto responded to this situation by amending its rooming house bylaw to implement a licensing procedure, tribunal, and working group in 1974 (City of Toronto, 1994).

Rooming houses have been correlated with poor health, with residents having much higher mortality rates and shorter life expectancy than accounting for low income alone (Hwang et. al., 2003). Rooming houses are also associated with extreme poverty, 
addiction, and poor mental health - particularly in Parkdale, which has a large concentration of rooming houses with a large post-deinstitutionalization population. However, rooming houses form an important part of the housing system in Canada, usually accommodating low-income persons and persons at risk of homelessness (Crystal \& Beck, 1992; CMHC, 2006, Pedersen \& Swanson, 2010). Additionally, although rooming houses are often thought by many to be temporary housing for transient individuals, the majority of tenants "rely on rooming houses for long-term housing, spending 20-30 years in multiple rooming houses" (Freeman, 2013).

Rooming houses are an important source of affordable housing in Toronto, which had a social housing waiting list of 102,049 households in 2019 (City of Toronto, 2019). Although rooming houses are often referred to as the "lowest rung of the housing ladder', Campsie (2018) notes that the metaphor of a ladder implies a linear upward motion while the reality is much more complicated and nuanced; people may be unable to or uninterested in changing rungs, and there is considerable lateral motion moving from one housing type to another that do not involve consecutive steps. In any case, rooming houses are one of the most affordable private-market housing options for lowincome households in Toronto, often existing as a step between homelessness and a trajectory of stable and secure housing (Freeman, 2014). In the 1970s and 1980s, rooming house residents were being evicted en masse, deadly fires were occurring in unregulated rooming houses. Accordingly, regulations and policy on rooming houses have been aimed at regulating market housing geared toward low-income households, 
with zoning regulations, licensing programs, and building inspections aimed to ensure a minimum living standard.

Governments are often caught in a double-bind of ensuring acceptable standards for habitation while recognizing that regulations may result in tenant dislocation and the removal of affordable housing units from a city's housing stock. The linkages between formality and informality, regulation and policies of (un)enforcement are often at the centre of the debate around affordable rental stock in the lower portions of the housing ladder. In Vancouver, there is an official policy of non-enforcement of building code regulations for secondary suites except in the case of complaints to ensure that affordable units are maintained (Mendez \& Quastel, 2015). Regulation on rooming houses, which fill a similar place in the housing system, have much of the same effectrooming house licensing that was put into place in the 1970s led to a dramatic drop in the number of rooming houses, dropping from around 1200 in 1974 to 620 in 1977 (Campsie, 2018). Rooming house owners who could not meet licensing requirements either gave up the businesses or continued to operate illegally (Campsie, 2018). The process of unidirectional increasingly onerous regulations has been called the "regulatory ratchet"-higher and higher standards causing the loss of affordable units they were meant to protect (Campsie, 2018).

Freeman (2014) has called for a framework for rooming houses to operate and become a better option for low-income households in need of housing, with effective regulation being important in improving the health and safety of rooming house residents. This is especially the case in Toronto, which since amalgamation has had a 
confusing and uneven regulatory regime, described by Freeman (2017) as being governed by 'ghost jurisdictions' - entities that have "been politically abolished but some of whose legal rules continue to be in form" (Valverde, 2012). Before amalgamation in 1998, rooming houses were zoned as permissible in particular areas of Downtown Toronto and South Etobicoke but prohibited in the inner suburbs of Scarborough and North York (Freeman, 2017). Since amalgamation, the zoning bylaws of the former municipalities were still valid, creating an uneven geography of regulation that makes a framework and strategy for rooming houses difficult. This uneven geography of legality compounded with the persistent need for private-market affordable rentals has led to the proliferation of illegal and unlicensed rooming houses in areas that rooming houses are not zoned as a permissible land use (Freeman, 2014). Housing workers and advocates speculate that there are more illegal than legal rooming houses in Toronto; a 2017 study by the Parkdale Neighbourhood Land Trust conducted a study that found 198 rooming houses in Parkdale, far greater than the 112 licensed rooming houses (Parkdale Neighbourhood Land Trust, 2017). These 198 rooming houses outnumbered the Toronto Community Housing units in the neighbourhood, making it an important source of affordable housing in the neighbourhood.

\section{Why is co-living having its big moment now?}

The conditions that have led to the global proliferation of co-living in the 2010s are complex. Gentrification has been a major force in both the loss of low-income rooming houses and the contemporary proliferation of co-living developments. The exact nature and definition of gentrification can be elusive, but it has been described as 
the "process of converting working-class areas into middle-class neighbourhoods through the rehabilitation of the neighbourhood's housing stock" (Smith, 1979; p. 547). On a theoretical level, gentrification has been described as the "upward class transformation of urban space" (Clark, 2005; Hackworth, 2007). After a period of suburbanization and the decline of inner-city neighbourhoods in the first half of the 1900s, there has been a return of investment and capital into inner cities. The process of gentrification has become ubiquitous by the first decade of the twenty-first century, and influence the socio-spatial landscape of urban areas globally (Smith, 2011; Wyly, 2018).

Smith (1979) characterized gentrification as a back-to-the-city movement of capital rather than people, noting that the "so-called urban renaissance has been stimulated more by economic forces than cultural forces," and that the consumer preference for profit and sound financial investment is the strongest force in determining the spatial distribution of gentrification (p. 540). Lees (2000) noted that since the start of systematic gentrification in the 1950s, the process has undergone significant changes. Hackworth \& Smith (2001) assembled a periodized history of gentrification, dividing the history of gentrification from the 1960 s to the 2000 s into three waves. Broadly, firstwave gentrification from the 1960 s to the late 1970 s was characterized as sporadic and state-led, and was justified through the "discourse of ameliorating urban decline" ( $p$. 466). The concentration of rooming houses in urban cores was facilitated by the urban decline that occurred as a result of suburbanization and the resulting disinvestment. Rooming houses were a stigmatized form of housing associated with poverty, and were 
often seen as a temporary land use before rent gaps developed to facilitate redevelopment.

Second-wave gentrification in the 1980s "surged as never before," and was integrated into a "wider range of economic and cultural processes at the global and national scales" (Hackworth \& Smith, 2001, pp. 466, 468). In the early 1990s, there was speculation that gentrification had run out of steam due to recession, negative equity in real estate, and other factors (Bourne, 1993). However, a third wave of gentrification followed, characterized by Hackworth \& Smith (2001) as a "expression of the economic conditions and processes that make reinvestment in disinvested inner-urban areas so alluring for investors" (p. 468). The third wave "pushed farther beyond the disinvested urban core, involved a much more prominent role for large developers with transnational portfolios, faced far less resistance given the previous rounds of displacement of working-class activists, and entailed a far more aggressive, interventionist role for the state, at multiple scales" (Wyly, 2018, p. 13). For example, neighbourhood change spurred on by municipal-led transit-oriented development reduced the supply of privatemarket affordable housing in Metro Vancouver (Jones \& Ley, 2016). Cities have increasingly adopted urban revitalization policies that aim to promote economic upgrading in inner-city areas where low-rent rooming houses have typically been concentrated (Smith, 2002; Davidson, 2007).

An effect of these forces has been the changes in the distribution of income groups, with downtown areas increasingly becoming high-income areas. Hulchanski (2011) has noted the increasing income polarization and changing spatial distribution of 
income groups in Toronto, with increasing concentration of high-income individuals in the inner city and increases in low-income individuals in the inner suburbs. Rooming houses in Toronto have concurrently experienced a process of suburbanization as the inner city experiences gentrification and inner-city rooming houses decrease in number. While it is difficult to determine where illegal rooming houses are located in the City of Toronto, rooming house complaints received by the City of Toronto are correlated with the economic polarization noted by Hulchanski (2011).

The phenomenon of gentrification is most likely a mix of both cultural and economic factors. On the cultural front, there is an explanation among gentrification theorists that young, professional, middle-class people have changed their lifestyle, decreasing the relative desirability of single-family suburban homes (Lipton, 1977). These changes include trends toward fewer children, postponed marriages, increased divorce rates, preference for active modes of transport, among others (Smith, 1979; Lee et. al., 2019). Additionally, demographic factors, such as smaller household sizes and a growing preference to live alone in Western societies, has played important factors in accounting for neighbourhood change and gentrification (Ley, 1986; Klinenberg, 2012). The growing non-linearity and delay of life-stages, such as marriage, homeownership, and childbearing, are also factors that contribute to changes in housing choice (Townshend \& Walker, 2010; Moos, 2016). Cultural factors such as changes in commuting preferences also play a large factor in residential preferences and neighbourhood change. Co-living projects are typically located in walkable and bikeable inner-city districts that are well-served by public transit. 
On a similar vein, Moos (2016) has noted that concentrations of young adults in central cities have grown dramatically since the 1960s, coining the term youthification to describe the process. Gentrification and youthification differ but are not mutually exclusive; while gentrification is explicitly a class-based process, youthification refers to the increase in younger demographics. The millennial generation, generally defined as the cohort born between 1981 and 1996 and has become the largest birth cohort in Canada since 2019 at 27 percent of the population (Heisz \& Richards, 2019). Lee et. al. (2019) identified three latent classes of Millennials and Gen-Xers in California: the Younger, Pro-Urban Class, who prefer urban amenities; the Affluent, Highly Educated Class, who pursue lifestyles and high socioeconomic status over homeownership or good school districts; and the Middle-Class Homeownership Class, preferring suburban homeownership lifestyles. Of the sample $(n=729)$, only 15 percent were part of the Middle-Class Homeowner Class, with the majority (53 percent) belonging to the Younger, Pro-Urban Class (Lee et. al., 2019). 


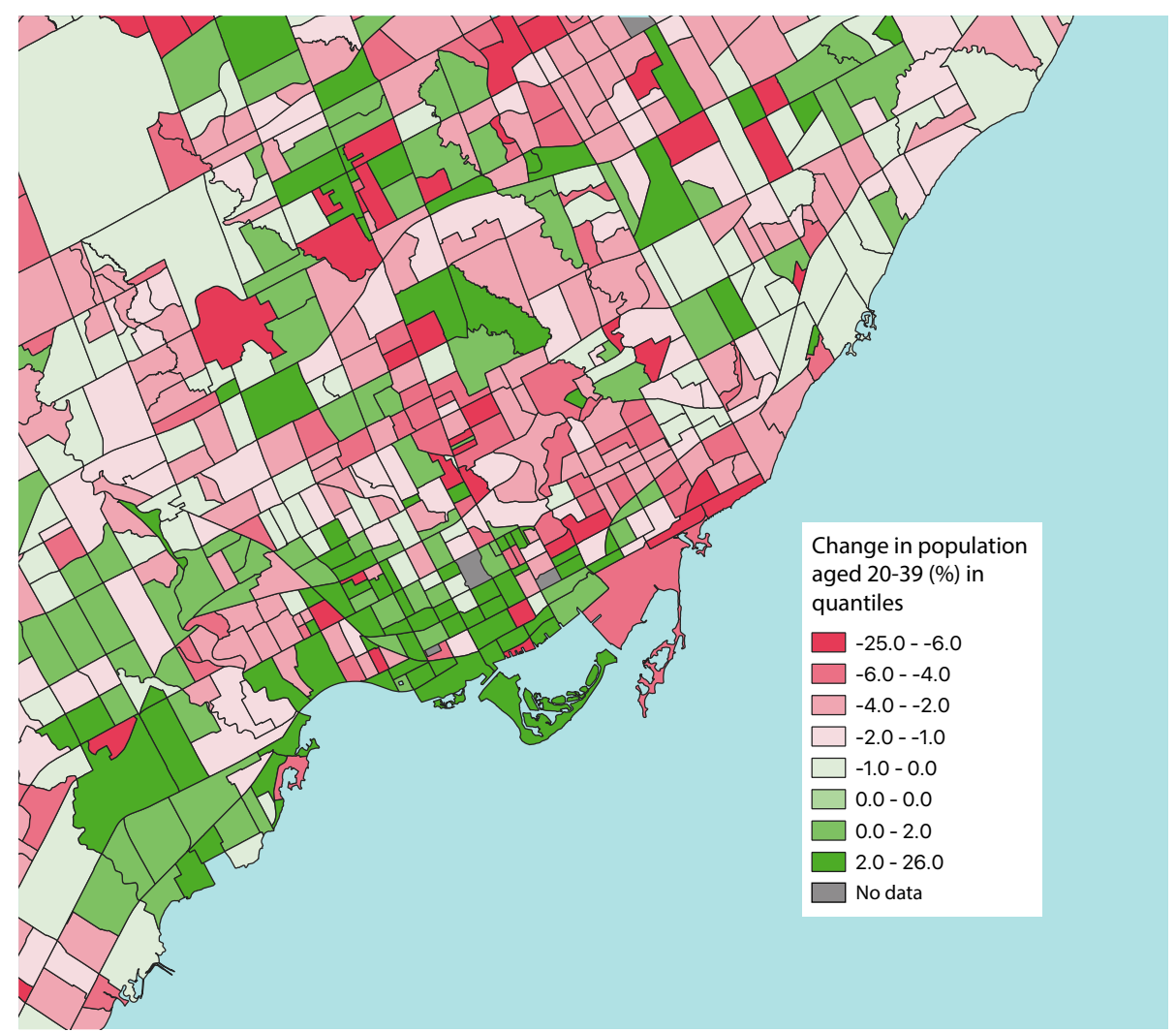

Figure 4: Change in population aged 20-39 in percentage, 2006-2016

Data from Statistics Canada $(2006,2016)^{1}$

The youthification of the inner city has had significant effects on urban housing markets; more than half of young adults are renters (Moos, 2016), and increased numbers of often affluent young people increase demand for limited housing. Additionally, population growth has been concentrated south of Bloor Street, especially in the Waterfront communities, which experienced a population change of over 30 percent, while the majority of the areas within the city experienced population loss

\footnotetext{
1 Cross-year census tract boundaries harmonized using Allen \& Taylor's (2018) Longitudinal Census Tract Database
} 
(Canadian Centre of Economic Analysis \& Canadian Urban Institute, 2019). A study conducted by the Canadian Centre for Economic Analysis (CANCEA) and the Canadian Urban Institute (CUI) found that "over 148,000 additional bedrooms would be needed to eliminate overcrowding in the rental market” (CANCEA \& CUI, 2019). Since the 1970s, there has been little purpose-built rental in Toronto, and only accounted for 6 percent of the development pipeline from 2011 to 2016 (CANCEA \& CUI, 2019). Inelastic land supply and an increase in high-income households have been found to crowd out lowerincome households (Gyourko et. al., 2013).

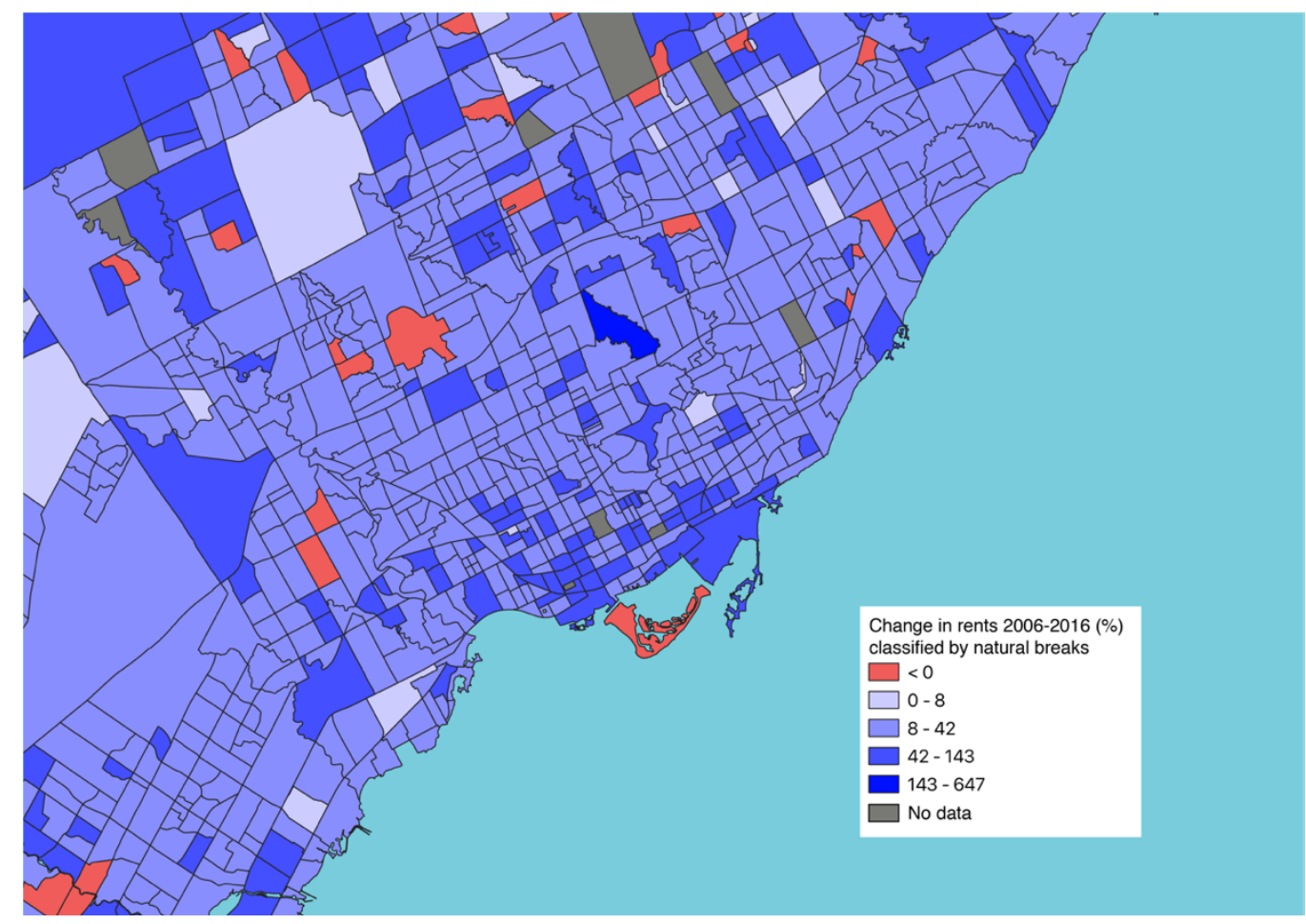

Figure 5: Change in average rents, 2006-2016 Data from Statistics Canada $(2006,2016)^{2}$

2 Cross-year census tract boundaries harmonized using Allen \& Taylor's (2018) Longitudinal Census Tract Database 
Starcity explicitly states that they are building for middle-income households and that their mission is to "house the backbone of every city: the teachers, police officers, firefighters, hospitality workers, students, baristas, bartenders, and entrepreneurs, which in turn makes cities accessible to everyone" (Starcity, n.d.). In San Francisco, median rents for a one-bedroom apartment was $\$ 3,479$ USD per month in March 2020, with two-bedroom apartments having a median rent of $\$ 4,500$ USD per month in the same period (Zumper, 2020). While the median household income of the city is also among the highest in the United States at \$96,265 USD in 2019, rents at that level would require 43 percent and 56 percent of the median household income for one- and two-bedroom apartments respectively. San Francisco's proximity to Silicon Valley has contributed to the high costs of housing, with high-wage households concentrating within the city.

Co-living companies such as Starcity offer rooms in San Francisco for as little as $\$ 1,600-$ significantly less than the monthly median rent of $\$ 2,550$ for a studio apartment in the city (Starcity, 2020; Zumper, 2020). Starcity provides housing at lower costs for people willing to rent smaller private spaces, making high-cost cities accessible for a wider range of people. However, when a city becomes unaffordable for core workers such as teachers and firefighters, we must consider: who are we building a city for?

\section{Selling 'authenticity' and the creative city}

Richard Florida's The Rise of the Creative Class (2002) has been eagerly embraced by mayors and economic development planners in the US as a model of 
understanding what makes successful cities work (Eakin, 2002; Florida, 2014). This new 'creative class' is understood to be geographically mobile and tends to concentrate in certain cities, drawn by various 'soft' factors, such as openness, tolerance, and amenity preferences (Florida, 2002). The amenity preferences of Richard Florida's 'creative class' is epitomized by an urban image of an animated street lined with coffee shops in a historic or 'bohemian' inner-city district (Clark et. al., 2002; Florida, 2002). This 'creative class' is characterized by a "restless search for authentic experiences" (Peck, 2005). The concept of authenticity is an ambiguous one and is most often used as an "elitist category of aesthetic judgement," referring to the "pursuit of identity in 'real' places, 'real' experiences and a 'real' self' (Zukin, 2009, pp. 544-545).

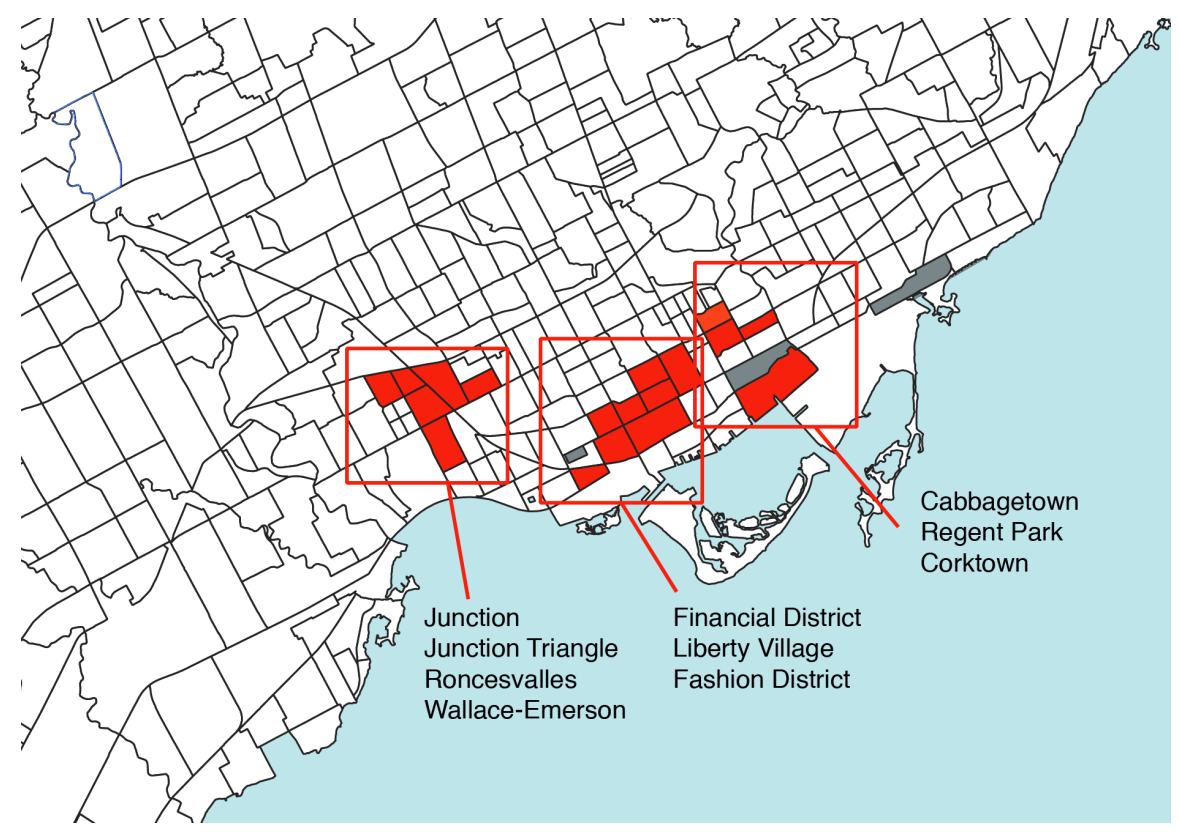

Figure 6: Locations of co-living units in Toronto operated by Soulrooms, SociableLiving, Roost, and Milyou 
When looking at co-living companies operating in cities worldwide, it is impossible not to notice striking similarities in the aesthetic sensibilities and cultural amenities that are being marketed. The cultural amenities offered and location choices of co-living companies are similar across cities on different continents. Co-living companies are located typically in central parts of cities, typically in 'bohemian' neighbourhoods with brewery- and cafe-lined streets. Co-living is marketed typically to people who fit the description of the 'creative class'. Node, a Toronto-based co-living company, describes its residents as "creatives, tech-savvies, and entrepreneurs who are shaping the world we live in" (Node, 2020). Node describes as 'curated living', bringing 'beautiful apartments and creative people together to form inspiring luxury coliving' (Node, 2020). Node operates 5 locations in New York, all located in the gentrifying neighbourhood of Bushwick, with units they describe as "perfectly curated...as unique as you are" (Node, 2020). Node locations have a "curator" who helps to facilitate move-in and show residents around the neighbourhood. Similarly, Sydney-based Uko describes co-living as being for "up and coming entrepreneurs and future innovators seeking to monetise their passion in their own unique way" (Uko, 2020).

The vocabulary and narratives used by co-living companies echo this yearning for authenticity_selling a pursuit of 'real' places, 'real' experiences, and a 'real' self. It is doubtless that the uniformity of aesthetic and cultural preferences seen across co-living companies worldwide is no mistake. The uniformity of the 'product' being marketed indicates that there is a specific demographic of young, pro-urban, relatively affluent, 
educated, mobile, 'experience'-focused people congregating in high-cost cities around the world willing to trade space and privacy for a sense of 'community' and an 'authentic urban experience'. Curiously, the mobility of this demographic undermines the rootedness that connects people to place, running contrary to the idea of authenticity of place. A global hegemonic urbanism has led to a certain standardization of desire (Zukin, 2002), allowing the trend of co-living to grow worldwide in such a quick fashion in the late 2010s.

Starcity frames itself as addressing the challenge to build housing for "everyone" because they "don't want to lose the amazing character of the cities we love" (Starcity, n.d.). Starcity also states that they are "[r]eviving the cities we love"-implying that the "cities we love" have lost vitality in recent years (Starcity, n.d.). What exactly is meant by 'character' and 'lost vitality' are left to the imagination of the reader. What is clear is that this search for authenticity has been influential in the claiming and transformation of urban space, often in conflicting and confusing ways with many moving to the city in search of authentic experiences in the process of gentrification, and others vying for preservation of a mythical "soul" of a city, ranging from activists to NIMBY homeowners. Low-income households are typically left out of this conversation as affordable housing options are lost in "revitalizing" areas-and co-living cannot address market housing for individuals and families with low incomes.

\section{Moving forward: co-living in Toronto and wider implications}

Despite considerable growth elsewhere and myriad co-living companies operating in and out of Toronto, there are yet to be ownership-style or purpose-built co- 
living projects in Toronto. Interestingly, various smaller cities, such as Manchester, Dublin, and Kitchener-Waterloo already have co-living projects operated by Node, a company based in Toronto and London. In the two former cities, Node operates in converted homes and units that they own, while in Kitchener, they are building the first purpose-built co-living project in Canada.

In two conversations with representatives from Toronto-based co-living companies, I discussed the future of co-living and what they saw the potential and limitations of the growth of co-living were, broadly as well as in Toronto. One was a real estate representative from a Toronto-based co-living company who wished to be anonymous, and Arnab Dastidar, co-founder of Soulrooms, a Toronto-based co-living management company. I also corresponded with Carola Perez-Book and Narmadha Rajakumar, Senior Planners at the City of Toronto, to speak about the current state and future of co-living in Toronto.

Representatives from both co-living companies based in Toronto I contacted indicated that they were both already working on expanding into the purpose-built coliving market in Toronto. The real estate representative indicated that they were looking for sites in Toronto to build co-living projects with more than 100 units. When asked about the potential he saw for co-living in the future, he stated that he saw great potential that this was going to change the way we live in cities. Going further, he believed that co-living is going to create a system for social housing, with communities based on common interests that can require residents with different levels of income. From this, 'true community' can be created, rather than places like the Regent Park 
redevelopment where different classes don't interact. The largest challenges he saw were in regulations and with getting lenders on board. The narratives espoused by this co-living representative are utopian and simplify the immense complexity of housing systems but illustrates well where co-living companies believe they are achieving.

The information about the impending entrance of purpose-built co-living in Toronto was corroborated by the planning department of the City of Toronto, who confirmed that there were two co-living pre-applications that the City had received recently. Currently, the zoning bylaw in Toronto limits multi-tenant dwellings to 25 rooms, applying to commercial-residential areas, but are reporting on proposals to increase the thresholds later in 2020 (C. Perez-Book, personal communication, Feb 21, 2020). A report is also being brought forward at the Planning and Housing Committee to expand rooming house legality and regulation across the city, although these are longterm efforts unrelated to the rise of co-living. As a part of this report, there will be a section about co-living, which they see as a rooming-house-type accommodation as there is no mechanism in zoning to determine the intended market of a project.

This means that the registry of licensed rooming houses would contain both lowincome rooming houses as well as co-living developments. This may complicate municipal strategies for managing and protecting low-cost market housing. For example, the City of Vancouver enacted its Single Room Accommodation (SRA) Bylaw in 2015 to prevent the "loss of low-income housing and the displacement of tenants in Vancouver's Downtown core (City of Vancouver, 2020). This bylaw protects SRO hotels, rooming houses, and other non-market housing with rooms less than 320 soft by 
regulating its alteration, conversion, and demolition, with a policy to replace SRA housing with self-contained units that are affordable for low-income singles. Similar proposals have been brought forth by the Parkdale Neighbourhood Land Trust in Toronto, although measures to protect rooming houses have not been adopted (Paradis, 2018). However, as low-cost market housing continues to disappear in the inner city, cities will need to grapple with the question of where these vulnerable populations will go. Interestingly, the practice of rooming may be coming full circle-with a similar differentiation between disappearing low-income rooming houses in the downtown core, suburban rooming houses populated by recent immigrants, and higherincome co-living projects in highly desirable central areas.

\section{Discussion}

The narrative that co-living is an innovative form of housing that will solve problems with housing affordability in high-cost cities should be met with some skepticism. The practice of rooming has existed in urban centres in various forms for at least a century, providing affordable housing for both individuals and families alike. Contemporary rooming houses provide some of the lowest-cost market rentals in urban centres including Toronto, which has a dearth of affordable rental units, an extremely low vacancy rate, increasing rents, and a long social housing waitlist. Co-living units, on the other hand, are typically slightly cheaper than market rates for studio apartments, but not by a significant margin.

In Toronto, co-living projects consist of private new-build high-end condos being managed by companies, with many companies looking to build purpose-built co-living 
spaces in the future. Unlike short-term rentals, these units are not taken out of the local rental market and operate like other rental units in terms of rental supply. However, SRO hotels and other low-cost rooming houses can sometimes converted into more expensive co-living projects. Co-living cannot easily be qualified as "good" or "bad" as the polarizing media coverage suggests. While the addition of additional rental units with a denser concentration of units can add much-needed housing supply in supplyconstrained housing markets, co-living developments will do little to address housing affordability on a broader scale-especially for lower-income individuals and families. The challenge of housing affordability differs for differing income groups. The filtering process is too slow and has a small effect on the provision of housing for low-income households and has seen a reversal in all Canadian metropolitan areas (Skaburskis, 2006). Without policy interventions in the ongoing process of gentrification, low-cost housing options will continue to be lost in urban centres.

While critiques of co-living often frame it as adult dorms and a dystopian result of runaway increases in housing costs, it is important not to respond to the effects of poor planning policies with more poor policies. While co-living is not a panacea for housing affordability, it can be a relatively affordable form of housing for a niche demographic of young professionals. In cities with restrictive zoning policies and extremely low vacancy rates such as Toronto, an increased supply of housing in all forms can help maintain affordability in various submarkets. Policymakers should re-examine restrictions on multi-tenant dwellings and remove unnecessary regulations on living arrangements that may be remnants of moralistic attitudes. 
My critique of co-living is levelled not on the form of living itself, but rather of the narratives of innovation, inclusivity, and affordability that many co-living companies are using to sell co-living. Individuals and families have lived in shared quarters in urban centres for millennia in many forms, such as in lodging houses, intentional co-housing communities, low-income rooming houses and SROs in urban centres, and the practice of collectively living in a dwelling with roommates. Co-living takes elements of many of these older forms of housing - and repackages it for a higher-income group.

What is a city for, and who does it belong to? These questions can contextualize the emergence of co-living for policymakers. Many cities lean on a vision of 'creative' and 'authentic' cities as a model for economic development, attracting capital and talent to locate there. The pursuit of becoming a "world-class city" has permeated public policy in cities across the world-but what does this mean? Those with more economic and cultural capital have a significant amount of power in claiming urban space and controlling the narrative of urban development. The creation of highly desirable cities and neighbourhoods can create situations where long-time residents see large increases in rents and evictions, simply because the spatial distribution of capital has shifted (Chum, 2014). This process has led to the loss of low-income rooming houses in Toronto and affordable housing options broadly. In the absence of investment in lowincome housing and the protection of existing low-income market housing, the number of unhoused individuals in Toronto may increase, and the social housing waitlist will continue to grow. While proponents of co-living present a narrative of inclusive, affordable, and sustainable living, they are selling a lifestyle product for a specific 
demographic. Because of the vague definition of co-living, it cannot be a part of municipal strategies for housing affordability broadly or the provision of low-income housing. However, municipalities should re-examine policies surrounding multi-tenant living broadly and destigmatize the practice of rooming to allow for a diverse range of housing options.

\section{Conclusions}

If patterns of gentrification and income polarization continue, low-cost rooming houses will likely continue to be lost in the inner city, with trends of suburbanization of poverty and rooming houses continuing as housing costs increase. Concurrently, coliving has grown globally, largely facilitated by the same forces of gentrification and neighbourhood change, indicating a set of economic and social conditions that are common in high-cost cities worldwide. Co-living is framed as an innovative solution to many modern ills of urban life, including high housing costs and isolation, addressing these problems by creating intentional communities and reducing the amount of private space and prioritizing shared amenities. However, the built form arrangements and utopian narratives of community are not new and have contemporary analogues in rooming houses and co-housing communities respectively. The narratives promoted by co-living companies often center authenticity in urban experiences and a pursuit of 'real' places, 'real' experiences, and a 'real' self-attracting a "creative class" that has been touted as a deciding factor in the success of a city. These narratives of intentional community and authenticity have been powerful in rebranding rooming from a 
stigmatized form of housing into a form of housing that people with means choose to live in.

Ultimately, the origins of co-living and whether or not it is 'innovative' is not important. However, it is important to recognize the ways that regulations have been and continue to be used as proxies to manage poverty, and the ways that gentrification and neighbourhood change are changing the urban landscape. The uneven legal landscape of rooming house policy in Toronto has seen many efforts toward harmonization since amalgamation but has faced many barriers due to stigma around the maligned form of housing. The destigmatization of rooming houses and other multidwelling homes and the city-wide legalization of this form of housing is long overdue in the landscape of suburbanization of poverty in Toronto and will bring thousands of households out of informality. On the other hand, the proliferation of co-living may complicate municipal strategies to protect and manage low-cost market housing and may be symptomatic of a housing system that is limiting structural densification, leading to solutions focused on fitting more people into smaller spaces. Co-living companies position themselves as bringing vitality, affordability, and authenticity back into the cities we love. The question that remains is: for whom? 


\section{References}

Allen, J., \& Taylor, Z. (2018). A new tool for neighbourhood change research: The Canadian longitudinal census tract database, 1971-2016. The Canadian Geographer / Le Géographe Canadien, 62(4), 575-588. doi:10.1111/cag.12467 Aronovici, C. (1917). Housing conditions in the city of Saint Paul. Retrieved from the Library of Congress, https://www.loc.gov/item/18003869/.

Bell v. R., [1979] 2 S.C.R. 212

Blank, J. (2001). Common meals in cohousing communities. Cohousing Journal (Winter), pp. 20-34. Retrieved December 15, 2019, from http://www.joaniblank.com/cohousing/CommonMeals/.

Bourne, L. (1993). The demise of gentrification? A commentary and prospective view. Urban Geography 14, 95-107.

Campsie, P. (1994) A brief history of rooming houses in Toronto, 1972-94. Rupert Community Residential Services, Toronto. Retrieved December 15, 2019, from http://www. ontariotenants.ca/research/rooming-houses.phtml.

Campsie, P. (2018). Rooming houses in Toronto, 1997-2018. Retrieved December 17, 2019, from http://neighbourhoodchange.ca/documents/2018/04/campsie-torontorooming-houses.pdf

Canadian Centre of Economic Analysis, \& Canadian Urban Institute. (2019). Toronto Housing Market Analysis (p. 57). Retrieved January 3, 2020, from https://www.toronto.ca/legdocs/mmis/2019/ph/bgrd/backgroundfile-124480.pdf 
Chiodelli, F. (2015). What Is Really Different between Cohousing and Gated Communities? European Planning Studies 23 (12): 2566-2581. doi:10.1080/09654313.2015.1096915.

Chiodelli, F., and V. Baglione. (2014). Living Together Privately: For a Cautious Reading of Cohousing. Urban Research \& Practice 7 (1): 20-34. doi:10.1080/17535069.2013.827905.

Chum, A. (2015). The impact of gentrification on residential evictions. Urban Geography, 36(7), 1083-1098. https://doi.org/10.1080/02723638.2015.1049480

City of Toronto Committee on Urban Renewal, Housing, Fire and Legislation. City of Toronto Rooming House Bylaw Study. September 26, 1974.

City of Toronto. (1977). City of Toronto Planning Board. Report on skid row.

City of Toronto. (1994). Rooming house licensing by-law. Chapter 285: Rooming houses. Bylaw No. 1994-0754. Retrieved from https://www1. toronto.ca/City\%20Of\%20Toronto/Municipal\%20 Licensing\%20\&\%20Standards/1-Files/PDFs/ Chapter285.pdf .

City of Toronto. (2019). Social Housing Waiting List Reports. Retrieved January 9, 2020, from https://www.toronto.ca/city-government/data-researchmaps/research-reports/housing-and-homelessness-research-and-reports/socialhousing-waiting-list-reports

City of Vancouver (2020). Single Room Accommodation (SRA) Bylaw. Retrieved from https://vancouver.ca/people-programs/single-room-accommodation-bylaw.aspx 
Clark, E. (2005). The Order and Simplicity of Gentrification: A Political Challenge. In: R. Atkinson \& G. Bridge, eds., Gentrification in a Global Context: The New Urban Colonialism, pp. 256-264. London: Routledge.

Clark, T. N., Lloyd, R., Wong, K., \& Pushpam, J. (2002). Amenities drive urban growth. Journal of Urban Affairs, 24(5), pp. 493-515.

CMHC. (2006). Profile of Rooming House Residents. Socio-Economic Series 06-019. Canada Mortgage and Housing Corporation.

Crystal, S., \& Beck, P. (1992). A Room of One's Own: The SRO and the Single Elderly. Gerontologist 32, pp. 84-92.

Davidson, M. (2007), Gentrification as Global Habitat: A Process of Class Formation or Corporate Creation? Transactions of the Institute of British Geographers NS 32, pp. $490-506$.

Dennis, R. (1994) Interpreting the apartment house: modernity and metropolitanism in Toronto, 1900-1930. Journal of Historical Geography 20 pp. 305-322

Dennis, R. (2000). 'Zoning' before zoning: The regulation of apartment housing in early twentieth century Winnipeg and Toronto. Planning Perspectives, 15(3), 267-299. https://doi.org/10.1080/026654300407463

Droste, C. (2015). German co-housing: An opportunity for municipalities to foster socially inclusive urban development? Urban Research \& Practice, 8(1), 79-92. https://doi.org/10.1080/17535069.2015.1011428

Eakin, E. (2002, June 1). The cities and their new elite. New York Times. Retrieved from https://www.nytimes.com/2002/06/01/arts/the-cities-and-their-new-elite.html. 
Fine, L. M. (1986). Between Two Worlds: Business Women in a Chicago Boarding House 1900-1930. Journal of Social History, 19(3), 511-519.

\section{https://doi.org/10.1353/jsh/19.3.511}

Florida, R. (2012). The rise of the creative class, revisited. New York: Basic Books.

Freeman, Lisa M. (2013). Making Room: The Geography of Rooming House Regulation in Toronto. PhD paper. University of Toronto.

Freeman, L. (2014). Toronto's Suburban Rooming Houses: Just a Spin on a Downtown "Problem"? Retrieved from https://www.wellesleyinstitute.com/wpcontent/uploads/2014/10/Suburban-Rooming-Houses-FINAL-Sept-24.pdf.

Freeman, L. (2017). Governed Through Ghost Jurisdictions: Municipal Law, Inner Suburbs and Rooming Houses. International Journal of Urban and Regional Research, 41(2), 298-317. https://doi.org/10.1111/1468-2427.12441

Gamber, W. (2005). Away from Home: Middle-Class Boarders in the NineteenthCentury City. Journal of Urban History, 31(3), 289-305. https://doi.org/10.1177/0096144204272415

Grant, J. L., Derksen, J., \& Ramos, H. (2019). Regulating marginality: How the media characterises a maligned housing option. International Journal of Housing Policy, 19(2), 192-212. https://doi.org/10.1080/19491247.2018.1436848

Grinde, B., Nes, R. B., MacDonald, I. F., \& Wilson, D. S. (2018). Quality of Life in Intentional Communities. Social Indicators Research, 137(2), 625-640. https://doi.org/10.1007/s11205-017-1615-3 
Groth, P. (1989) Living downtown: the history of residential hotels in the United States. University of California Press, Berkley and Los Angeles, CA.

Gyourko, J., Mayer, C., \& Sinai, T. (2013). Superstar Cities. American Economic Journal: Economic Policy, 5(4), 167-199. https://doi.org/10.1257/pol.5.4.167

Hackworth, J., \& Smith, N. (2001). The changing state of gentrification. Tijdschrift Voor Economische En Sociale Geografie, 92(4), 464-477. https://doi.org/10.1111/1467-9663.00172

Hackworth, J. (2007). The Neoliberal City. Cornell, NY: Cornell University Press.

Harris, R. (1992). The End Justified the Means: Boarding and Rooming in a City of Homes, 1890-1951. Journal of Social History, 26(2), 331-358.

\section{https://doi.org/10.1353/jsh/26.2.331}

Haven (2020). MEET OUR MEMBERS. Retrieved from https://www.havencoliving.com/meet-our-members

Heisz, A., \& Richards, E. (2019). Economic Well-being Across Generations of Young Canadians: Are Millennials Better or Worse Off? Retrieved from https://www150.statcan.gc.ca/n1/en/daily-quotidien/190418/dq190418ceng.pdf?st=IIBXqv3b.

Hulchanski, J. D. (2010). The three cities within Toronto: Income polarization among Toronto's neighbourhoods, 1970-2005. Cities Centre, University of Toronto.

Hwang, S. W., Martin, R. E., Tolomiczenko, G. S., \& Hulchanski, J. D. (2003). The Relationship Between Housing Conditions and Health Status of Rooming House 
Residents in Toronto. Canadian Journal of Public Health, 94(6), 436-440. https://doi.org/10.1007/BF03405081

Jakobsen, P., \& Larsen, H. G. (2019). An alternative for whom? The evolution and socio-economy of Danish cohousing. Urban Research \& Practice, 12(4), 414430. https://doi.org/10.1080/17535069.2018.1465582

Jarvis, H. (2011). Saving Space, Sharing Time: Integrated Infrastructures of Daily Life in Cohousing. Environment and Planning A: Economy and Space, 43(3), 560-577. https://doi.org/10.1068/a43296

Jones, C. E., \& D. Ley (2016), Transit-oriented Development and Gentrification along Metro Vancouver's Low-Income SkyTrain Corridor. The Canadian Geographer, 60, pp. 9-22.

Kläser, S. (2006). Selbstorganisiertes Wohnen. Arch plus 176-177: 90-96.

Klinenberg, E. (2012), Going Solo: The Extraordinary Rise and Surprising Appeal of Living Alone. New York: Penguin Books.

Krokfors K. (2012). Co-housing in the making. Built Environment 38(3): 309-314.

Lee, Y., Circella, G., Mokhtarian, P. L., \& Guhathakurta, S. (2019). Heterogeneous residential preferences among millennials and members of generation $\mathrm{X}$ in California: A latent-class approach. Transportation Research Part D: Transport and Environment, 76, 289-304. https://doi.org/10.1016/j.trd.2019.08.001

Lees, L. (2000). A reappraisal of gentrification: Towards a 'geography of gentrification.' Progress in Human Geography, 24(3), 389-408. https://doi.org/10.1191/030913200701540483 
Ley, D. (2003). Artists, Aestheticisation and the Field of Gentrification. Urban Studies, 40(12), 2527-2544. https://doi.org/10.1080/0042098032000136192

Lipton, S. G. (1977). Evidence of central city revival. Journal of the American Institute of Planners 43, April: 136-47.

Mahdawi, A. (2017, November 16). Silicon Valley thinks it invented roommates. They call it 'co-living'. Retrieved from https://www.theguardian.com/commentisfree/2017/nov/16/silicon-valley-thinks-itinvented-roommates-they-call-it-co-living

McCamant, K., \& Durrett, C. (2011). Creating cohousing: Building sustainable communities. New Society Publishers.

Mendez, P., \& Quastel, N. (2015). Subterranean Commodification: Informal Housing and the Legalization of Basement Suites in Vancouver from 1928 to 2009: SUBTERRANEAN COMMODIFICATION. International Journal of Urban and Regional Research, 39(6), 1155-1171. https://doi.org/10.1111/1468-2427.12337

Modell, J., \& Hareven, T. K. (1973). Urbanization and the malleable household: An examination of boarding and lodging in American families. Journal of Marriage and Family, 35(3), 467-479. doi:10.2307/350582

Moos, M. (2016). From gentrification to youthification? The increasing importance of young age in delineating high-density living. Urban Studies, 53(14), 2903-2920. https://doi.org/10.1177/0042098015603292

Ontario Human Rights Commission. (2013). Report on the inquiry into rental housing licensing in the city of Waterloo. 
Parkdale Neighbourhood Land Trust. (2017). No Room For Unkept Promises, Parkdale Rooming House Study. Retrieved from http://www.pnlt.ca/wpcontent/uploads/2017/05/Parkdale-Rooming-House-Study Full-Report V1.pdf

Pedersen, W. \& J. Swanson (2010). Pushed Out: Escalating Rents in the Downtown Eastside. Carnegie Community Action Project, Vancouver. Retrieved from https://Homelesshub.ca/resource/ pushed-out-escalating-rents-Downtowneastside.

Pownall, A. (2020, January 24). PriestmanGoode to design interiors of vast Indian coliving spaces. Retrieved from https://www.dezeen.com/2020/01/24/priestmangoode-olive-co-living-indiainteriors-branding/

Pusey, A., \& Chatterton, P. (2017). Commons. In Urban Theory: New Critical Perspectives, edited by M. Jayne and K. Ward, 63-73. Abingdon: Routledge.

Ruiu, M. L. (2014). Differences between Cohousing and Gated Communities: A Literature Review. Sociological Inquiry 84 (2): 316-335. doi:10.1111/soin.12031.

Ruiu, M. L. (2016). The Social Capital of Cohousing Communities. Sociology, 50(2), 400-415. https://doi.org/10.1177/0038038515573473

Rollinson, P. (1991). The spatial isolation of elderly single-room-occupancy hotel tenants. The Professional Geographer 43: 456-464

Sanguinetti, A., \& Hibbert, K. (2018). More room for cohousing in the United States: Understanding diffusion potential by exploring who knows about, who likes, and 
who would consider living in cohousing. Housing and Society, 45(3), 139-156. https://doi.org/10.1080/08882746.2018.1529507

Sargisson, L. (2010). Cohousing: A Utopian property alternative? Retrieved February 20, 2012, from http://www.psa.ac.uk/2010/UploadedPaperPDFs/1225 1085.pdf.

Sargisson, L. (2012). Second-Wave Cohousing: Utopian Studies, 23(1), 28.

\section{https://doi.org/10.5325/utopianstudies.23.1.0028}

Scheller, D., \& Thörn, H. (2018). Governing 'Sustainable urban development' through Self-Build groups and Co-Housing: The cases of Hamburg and Gothenburg. International Journal of Urban and Regional Research, 42(5), 914933. doi:10.1111/1468-2427.12652

Skaburskis, A. (2006). Filtering, City Change and the Supply of Low-priced Housing in Canada. Urban Studies, 43(3), 533-558.

https://doi.org/10.1080/00420980500533612

Smith, N. (1979). Toward a Theory of Gentrification A Back to the City Movement by Capital, not People. Journal of the American Planning Association, 45(4), 538548. https://doi.org/10.1080/01944367908977002

Smith, N. (2002), New Globalism, New Urbanism: Gentrification as Global Urban Strategy. Antipode 34, pp. 427-450.

Starcity (n.d.). Urban Revival. Retrieved from https://starcity.com/urban-revival Statistics Canada. (2006). Census of Population, 2006: Census Tract (CT) Profiles, [Table]. Retrieved from 
http://datacentre.chass.utoronto.ca.ezproxy.lib.ryerson.ca/cgibin/census/2006/displayCensusCT.cgi

Statistics Canada. (2016). Census of Population, 2016: Census Tract (CT)

Profiles, [Table]. Retrieved from

http://datacentre.chass.utoronto.ca.ezproxy.lib.ryerson.ca/cgi-

bin/census/2016/displayCensus.cgi?year=2016\&geo=ct

Stey (2020). Stay - Wangfujing. Retrieved from https://www.stey.com/en-US/wfj.

The Collective (n.d.). "About The Collective." About Us I Join The Global Living

Movement I The Collective. Retrieved from www.thecollective.com/about-us.

Townshend I and Walker RC (2010) Life course and lifestyle changes: Urban change through the lens of demography. In: Bunting T, Filion P and Walker R (eds) Canadian Cities in Transition: New Directions in the Twenty-First Century (4th edition). Don Mills: Oxford Uni- versity Press, pp. 131-149.

Tummers, L. (2015). Understanding co-housing from a planning perspective: Why and how? Urban Research \& Practice, 8(1), 64-78.

\section{https://doi.org/10.1080/17535069.2015.1011427}

Tummers, L. (2016). The re-emergence of self-managed co-housing in Europe: A critical review of co-housing research. Urban Studies, 53(10), 2023-2040.

\section{https://doi.org/10.1177/0042098015586696}

Uko (n.d.). Home - UKO. Retrieved from https://uko.com.au

Valverde, M. (2012) Everyday law on the street: city governance in an age of diversity. University of Chicago Press, Chicago, IL and London. 
Walks, A., \& August, M. (2008). The Factors Inhibiting Gentrification in Areas with Little Non-market Housing: Policy Lessons from the Toronto Experience. Urban Studies, 45(12), 2594-2625. https://doi.org/10.1177/0042098008097102

Weaver, J.C. (1987) The North American apartment building as a matter of business and an expression of culture: a survey and case study. Planning Perspectives 2, pp. 27-52.

Wolfe, A. (1906) The Lodging House Problem in Boston. New York: Houghton, Mifflin and Company.

Wyly, E. (2019). The Evolving State of Gentrification: The Evolving State Of Gentrification. Tijdschrift Voor Economische En Sociale Geografie, 110(1), 1225. https://doi.org/10.1111/tesg.12333

WeLive (n.d.). About WeLive - Fully Furnished Apartments in NYC \& DC Area.

Retrieved from https://www.welive.com/about/

Zukin, S. (2009). Changing Landscapes of Power: Opulence and the Urge for Authenticity. International Journal of Urban and Regional Research, 33(2), 543553. https://doi.org/10.1111/j.1468-2427.2009.00867.x

Zumper (2020). Average Rent in San Francisco - San Francisco Rental Data and Trends - Zumper Research. Retrieved March 31, 2020 from https://www.zumper.com/research/average-rent/san-francisco-ca. 